\title{
Getting Hooked on Supramolecular Coordination Chemistry
}

\author{
Katharina M. Fromm*
}

\begin{abstract}
The author describes the beginnings of her research in Switzerland, the inspiration she received from her senior colleagues as well as her first successful research results in the chemistry of alkaline earth metal aggregates and silver coordination polymer networks. Her current interest lies in the design of smart materials, using different building blocks from previous projects. These projects evolved in Geneva, Karlsruhe, Basel, and Fribourg, where she became a full professor in 2006.
\end{abstract}

Keywords: Coordination chemistry · Cluster compounds · Single-source oxide precursors · Supramolecular chemistry · University of Geneva

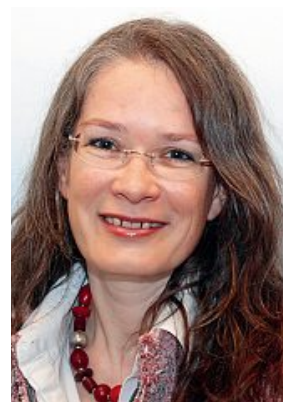

When I first arrived in Geneva on February 1st, 1998, it was bitterly cold with a fantastic blue sky, and therefore just the opposite of what everyone had warned me - the eternal winter fog. Just as clear as the weather was the lab which I moved into in the Rez de Chaussée. Nevertheless, chemistry needs little to get started, and the lucky coincidence of a lab emptying at CERN allowed me to inherit a large amount of glassware (... and to leave a black hole behind?). Two persons helped me to get started in different ways: Alan Williams offered the position of a $M a \hat{\imath}^{-}$ tre Assistante, and introduced me to the art of writing research proposals for the SNF, while Claude Piguet generously offered the informatics hardware to put the project on paper. With this help, my first SNF-project was under way, and I could start with one PhD student, Estelle Gueneau. Luckily, research went well, and -

${ }^{*}$ Correspondence: Prof. Dr. K. M. Fromm Department of Chemistry

University of Fribourg

Chemin du Musée 9

$\mathrm{CH}-1700$ Fribourg

Tel.: + 41263008732

Fax: + 41263009738

E-mail: katharina.fromm@unifr.ch with the aim of making new precursors for the low-temperature synthesis of superconductors - we obtained a series of alkali and alkaline earth metal clusters with hydroxy, alkoxy and aryloxide ligands (Fig. 1). ${ }^{[1]}$ The cyclic versions of the latter initiated us to investigate $s$-group metal derivatives of calix[n]arenes $(\mathrm{n}=$ 4, Fig. 2, see ref. [2]). The larger ones, namely the calix[8]arenes, are difficult to handle and crystallize, but once they do, they show promising ion conducting properties, as we were able to show later. ${ }^{[3]}$ We also started to use crown-ether compounds as scaffolds for ion-conducting solid-state compounds. ${ }^{[4]}$

Still pursuing the idea of making single-source precursors for oxide materials, we developed a multi-topic ligand series in order to coordinate selectively two different metal ion types at the different donor sites of the ligand. A second $\mathrm{PhD}$ student joined the group, Adeline Robin, and she focused on $\mathrm{Cu}$ - and $\mathrm{Ag}$-compounds for her thesis. At this point, the group started research in the field of coordination polymer compounds and crystal engineering (Fig. 3). ${ }^{[5]}$

At that time, we three girls squeezed into a small lab at the end of the first-floor corridor of the Chemistry building, where we shared one hood. With more and more results at hand, discussions with Alan, Claude, Res Hauser, Jacques Weber, Christian Bochet, Tomek Wesolowski, and Eric Vauthey allowed me to progress in many aspects of chemistry and physical properties of our compounds. Another important discussion partner was Gérald Bernardinelli in terms of structure solution and refinement. Later, as Alan was leaving for a sabbatical in Australia, I was able to add 'teaching' to my CV by taking over some of his lectures, certainly an important issue for the later career. After four years, my

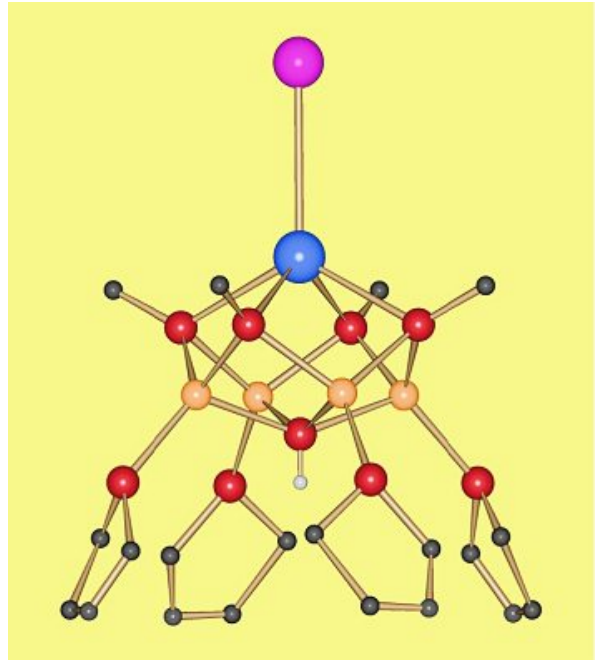

Fig. 1: $\left[\mathrm{IM}(\mathrm{OtBu})_{4}\{\mathrm{Li}(\mathrm{thf})\}_{4}(\mathrm{OH})\right], \mathrm{M}=\mathrm{Ca}, \mathrm{Sr}, \mathrm{Ba}$, Eu, Sm

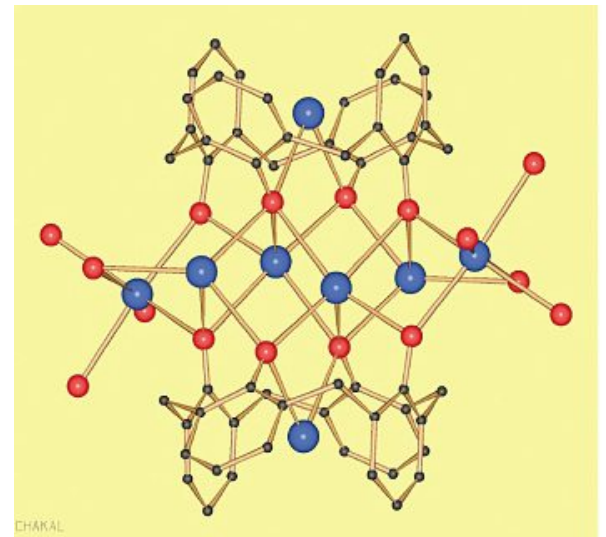

Fig. 2: $\left[\mathrm{K}_{8}(\text { calix }[4] \mathrm{arene})_{2}(\text { thf })_{8}\right]$

group moved back to the ground floor, I submitted my habilitation in Geneva, and became a 'doctor mother' for the first time with Estelle. I also applied for an Emmy Noether Part II stipend of the DFG as well as a SNF-professorship which were both 


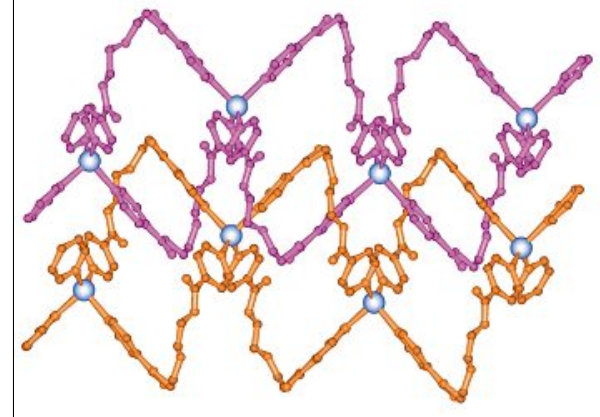

Fig. 3: A polycatenane: $\left[\mathrm{Ag}(\mathrm{L})_{2}\left(\mathrm{PF}_{6}\right)\right]$ $\left(\mathrm{L}=\mathrm{C}_{18} \mathrm{H}_{20} \mathrm{~N}_{2} \mathrm{O}_{5}\right)$

awarded. Thus, in October 2002, I built up a research group in Karlsruhe with three students, while still coaching Adeline in Geneva. The group was reunited in Basel as of June 2003. After another three years came the offer from Fribourg, and here I am now, again with an 'old' colleague from Geneva, Christian Bochet. I enjoy keeping in touch with my dear colleagues from $\mathrm{Ge}$ neva, Alan, Claude and Res, sharing chemistry and friendship.

Today, I am still hooked on cluster compounds, metal-organic frameworks and single-source precursors for oxide materials. Over the past years, I have added new aspects to my research, e.g. the nanoparticular aspects of our materials, ${ }^{[6]}$ as well as applications of our compounds in medicine. ${ }^{[7]}$ In this latter field, we are particularly interested in the generation of antimicrobial surface coatings for implants, which allows us to do highly interdisciplinary and exciting research, combining chemistry, apart from medicine, also with materials sciences, physics, microbiology, biology and biochemistry.

Received: September 29, 2009

[1] K. M. Fromm, Chem. Comm. 1999, 17, 1659; K. M. Fromm, G. Bernardinelli, H. Goesmann, M.-J. Mayor-Lopez, J. Weber, Z. Anorg. Allg. Chem. 2000, 626, 1685; K. M. Fromm, G. Bernardinelli, H. Goesmann, Polyhedron, 2000, 19, 1783; K. M. Fromm, E. D. Gueneau, H. Goesmann, Chem. Comm. 2000, 2187; K. M. Fromm, Chem. Eur. J. 2001, 7, 2236; K. M. Fromm, G. Bernardinelli, Z. Anorg. Allg. Chem. 2001, 627, 1626; K. M. Fromm, E. D. Gueneau, J.-P. Rivera, G. Bernardinelli, H. Goesmann, Z. Anorg. Allg. Chem. 2002, 628, 171; K. M. Fromm, Cryst. Eng. Comm., 2002, 4, 318; K. M. Fromm, Chimia, 2002, 56, 676; K. M. Fromm, E. D. Gueneau, H. Goesmann, C. Bochet, Z. Anorg. Allg. Chem. 2003, 629, 597; K. M. Fromm, E. D. Gueneau, G. Bernardinelli, H. Goesmann, J. Weber, M.-J. Mayor-López, P. Boulet, H. Chermette, J. Am. Chem. Soc. 2003, 125, 3593; K. M. Fromm, E. D. Gueneau, A. Y. Robin, W. Maudez, J. Sague, R. Bergougnant, Z. Anorg. Allg. Chem. 2005, 631, 1725; W. Maudez, T. Vig-Slenters, L. Mirolo, A. Fleury, K. M. Fromm, Main Group Chemistry 2006, 5, 41; W. Maudez, M. Meuwly, K. M. Fromm, Chem. Eur. J. 2007, 13, 8302; K. M. Fromm, Dalton Transactions, 2006, 43, 5103; K. M. Fromm, Coord. Chem. Rev. 2008, 252, 856.

[2] E. D. Gueneau, K. M. Fromm, H. Goesmann, Chem. Eur. J. 2003, 9, 509.

[3] R. D. Bergougnant, A. Y. Robin, K. M. Fromm, Tetrahedron 2007, 63, 10751.

[4] M. Dulak, R. Bergougnant, K. M. Fromm, H. R. Hagemann, A. Y. Robin, T. A. Wesolowski, Spectrochim. Acta A 2005, 64, 532; K. M. Fromm, R. D. Bergougnant, A. Y. Robin, $Z$. Anorg. Allg. Chem. 2006, 632, 828; M. G. Zolotukhin, G. Hernández, M. del Carmen, A. M. Lopez, L. Fomine, G. Cedillo, A. Nogales, T. Ezquerra, D. Rueda, H. M. Colquhoun, K. M. Fromm, A. Ruiz-Treviño, M. Ree, Macromolecules 2006, 39, 4696; K. M. Fromm, R. D. Bergougnant, Solid State Sciences 2007,
9, 580; A. Y. Robin, K. M. Fromm, Coord. Chem. Rev. 2006, 250, 2127.

[5] A. Y. Robin, K. M. Fromm, H. Goesmann, G. Bernardinelli, Cryst. Eng. Comm. 2003, 5, 405; K. M. Fromm, A. Y. Robin, M. Meuwly, H. Goesmann, G. Bernardinelli, Cryst. Eng. Comm. 2004, 6, 336; K. M. Fromm, A. Y. Robin, M. Meuwly, H. Goesmann, G. Bernardinelli, Cryst. Eng. Comm. 2004, 6, 336; R. D. Bergougnant, A. Y. Robin, K. M. Fromm, Cryst. Growth \& Design 2005, 5, 1691; J. L. Sagué Doimeadios, A. Y. Robin, K. M. Fromm, Chem. Commun. 2005, 36, 4548; A. Y. Robin, J. L. Sagué, K. M. Fromm, Cryst. Eng. Comm. 2006, 8, 403; J. L. Sague, K. M. Fromm, Crystal Growth \& Design 2006, 6, 1566; A. Y. Robin, J. L. Sagué Doimeadios, A. Néels, T. Vig Slenters, K. M. Fromm, Inorg. Chim. Acta 2007, 360, 212.

[6] K. Belser, T. Vig Slenters, C. Pfumbizai, G. Upert, L. Mirolo, K. M. Fromm, H. Wennemers, Angew. Chem. Int. Ed. 2009, 20, 3661.

[7] P. S. Brunetto, K. M. Fromm, Chimia 2008, 62, 249; T. Vig. Slenters, I. Hauser-Gerspach, A. U. Daniels, K. M. Fromm, J. Mat. Chem. 2008, 18, 5359; C. R. Arciola, N. Balaban, L. Baldassarri, K. Fromm, G. M. Hansch, U. Obst, E. Presterl, S. Stefani, J. Verran, L. Visai, Int. J. Artificial Organs 2008, 31, 858 . 